\title{
Genetic variation and population structure in Fraser fir (Abies fraseri): a microsatellite assessment of young trees
}

\author{
Kevin M. Potter, John Frampton, Sedley A. Josserand, and C. Dana Nelson
}

\begin{abstract}
The island-like populations of Fraser fir (Abies fraseri (Pursh) Poir.) have been isolated since the end of the late-Wisconsinian glaciation on the highest peaks of the Southern Appalachian Mountains and therefore offer an opportunity to investigate the genetic dynamics of a long-fragmented forest tree species. An analysis of eight microsatellite markers isolated from Fraser fir found that the species was out of Hardy-Weinberg equilibrium, with a significant deficiency of heterozygosity and a high degree of inbreeding $\left(F_{\text {IS }}=0.223\right)$ relative to other conifers, perhaps associated in part with the young life stage of the trees included in the analysis. The analysis detected a significant but small amount of genetic differentiation among Fraser fir populations $\left(F_{\mathrm{ST}}=0.004\right)$ and revealed that the geographical and latitudinal distances between populations, but not population area, were significantly correlated with their pairwise genetic differences. Both gene flow and postglacial migration history may have influenced the genetic architecture of the species. The results will be useful in the genetic conservation of Fraser fir, a species experiencing severe mortality following infestation by an exotic insect.
\end{abstract}

Résumé : Les populations de type insulaire de sapin de Fraser (Abies fraseri (Pursh) Poir.) sont demeurées isolées sur les plus hauts sommets du sud des Appalaches depuis la fin de la glaciation du Wisconsinien supérieur. Elles représentent donc une occasion d'étudier la dynamique des populations chez une espèce forestière fragmentée depuis longtemps. L'analyse de huit loci de microsatellites isolés chez le sapin de Fraser a permis de mettre en évidence que l'espèce était en déséquilibre d'Hardy-Weinberg, avec une déficience significative en hétérozygotes et un niveau élevé d'endogamie $\left(F_{\mathrm{IS}}=\right.$ 0,223 ) par rapport aux autres conifères. Ce résultat est possiblement relié en partie au fait que des arbres au stade juvénile ont été inclus dans l'étude. L'analyse a permis de détecter un niveau significatif mais faible de différenciation génétique parmi les populations de sapin de Fraser $\left(F_{\mathrm{ST}}=0,004\right)$. Les distances géographiques et latitudinales séparant les populations, et non leurs régions d'appartenance, étaient corrélées significativement avec leurs différences génétiques par paire. Le flux génique ainsi que l'histoire migratoire post-glaciaire ont pu avoir une influence sur l'architecture génétique de l'espèce. Les résultats permettront de guider les efforts de conservation chez le sapin de Fraser, une espèce qui connaît une forte mortalité due à une infestation causée par un insecte exotique.

[Traduit par la Rédaction]

\section{Introduction}

Fraser fir (Abies fraseri (Pursh) Poir.) offers the opportunity to investigate the long-term genetic dynamics of a tree species consisting of relatively small populations that have been isolated for thousands of years. Such species with restricted ranges generally exhibit lower levels of genetic variation than more widespread congeners (Gitzendanner and Soltis 2000; Godt and Hamrick 2001), although the genetic

Received 28 November 2007. Accepted 21 April 2008.

Published on the NRC Research Press Web site at cjfr.nrc.ca on 27 June 2008.

K.M. Potter ${ }^{\mathbf{1}, 2}$ and J. Frampton. Department of Forestry and Environmental Resources, North Carolina State University, Raleigh, NC 27695-8002, USA.

S.A. Josserand and C.D. Nelson. Southern Institute of Forest Genetics, USDA Forest Service, Southern Research Station, 23332 Mississippi 67, Saucier, MI 39574, USA.

${ }^{1}$ Corresponding author (e-mail: kpotter@ncsu.edu).

${ }^{2}$ Present address: Department of Forestry and Environmental Resources, North Carolina State University, 3041 Cornwallis Road, Research Triangle Park, NC 27709, USA. structure of rare species may be determined by their evolutionary history as well as by their life history attributes (Duminil et al. 2007). Fraser fir is endemic to a handful of the highest ridge systems in the Southern Appalachian Mountains in the states of North Carolina, Tennessee, and Virginia (Fig. 1), where it occurs almost entirely at elevations above $1300 \mathrm{~m}$, usually in association with red spruce (Picea rubens Sarg.) at lower elevations and as the dominant tree species above $1800 \mathrm{~m}$ (Busing et al. 1993).

During the peak of the late-Wisconsin glacial period, 18000 years to 12500 years ago, firs existed in mixed boreal forests across much of the southeastern United States, but warming climate conditions eliminated lower-elevation fir stands by 8000 years ago (Delcourt and Delcourt 1984). Such fragmentation may have negative genetic consequences because small population size may be accompanied by genetic drift and inbreeding and because isolation decreases the amount of gene flow among populations (Young et al. 1996). A small amount of gene flow among isolated plant populations, in the form of pollen or seed dispersal, may be enough to avert genetic drift and inbreeding (Ellstrand 1992) but is less likely to occur with greater spatial isolation. The genetic architecture of Fraser fir populations, therefore, may 
Fig. 1. Distribution of Fraser fir (Abies fraseri) in the Southern Appalachians of North Carolina, Tennessee, and Virginia.

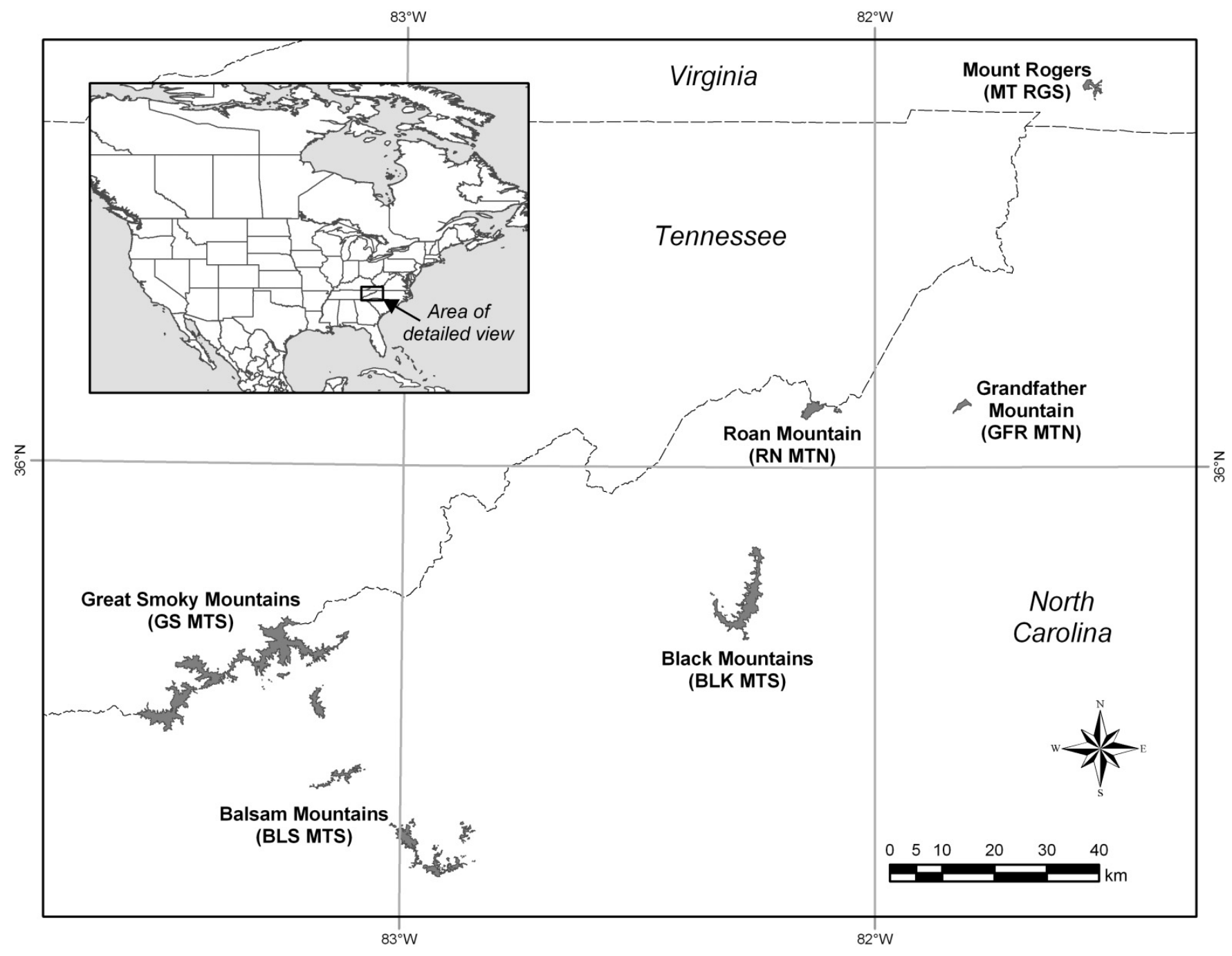

be determined by the counteracting forces of $(i)$ genetic drift and inbreeding, which tend to diminish within-population genetic diversity and increase among-population differentiation, and (ii) gene migration, which tends to increase among-population genetic diversity and decrease amongpopulation differentiation. At the same time, the genetic structure of a forest tree species such as Fraser fir may be affected by the scale of fragmentation, its pollination biology, and its evolutionary history (Young and Boyle 2000).

Assessments of Fraser fir allozymes and growth characteristics have detected significant genetic differences among its populations. A study of five allozyme markers in Fraser fir concluded that allelic frequencies differed slightly but significantly among five of the species' populations, most likely as a result of locally restricted mating and genetic drift (Ross 1988). This research further determined that the most isolated population, Mount Rogers in Virginia, was probably a genetic outlier; a separate isozyme analysis of three Fraser fir populations also found that the Mount Rogers population somewhat differentiated from two southern Fraser fir populations (Jacobs et al. 1984). A Christmas tree growth trial using open-pollinated seeds from the same five populations as Ross' (1988) work found that trees from low- elevation and more southerly sources grew more quickly than those from high-elevation and more northerly sources (Arnold et al. 1994). Recent research encompassing all six major Fraser fir populations has confirmed these results, finding highly significant population differences in lateral branch frost damage (Emerson et al. 2006) and in height growth and crown density, although more variation in height growth and crown density existed among families within populations than among populations (Emerson et al. 2008).

The current study is the first to use highly variable microsatellites to investigate the genetic composition of Fraser fir, is the largest Fraser fir marker study to date, and is the first encompassing all of the major populations of the species. We used microsatellite molecular markers isolated from Fraser fir (Josserand et al. 2006) to (i) quantify the genetic architecture of Fraser fir, including whether interpopulation gene flow has had an effect on the genetic characteristics of these populations, and (ii) assess whether the geographic characteristics of populations, such as area, isolation, elevation, and latitude, are associated with their genetic characteristics. The results are assisting in the completion of an ex situ gene conservation strategy for Fraser fir, which has been decimated in recent decades by the exotic balsam 
woolly adelgid (Adelges piceae Ratz.) (Dull et al. 1988) and may be further vulnerable to extirpation because of global climate change (Delcourt and Delcourt 1998).

\section{Materials and methods}

\section{Sample collection and DNA extraction}

This study encompassed 302 foliage samples representing the six major Fraser fir populations (Table 1). Each sample was grown from open-pollinated seed collected from a different mother tree (representing 302 mother trees) during an exceptional cone production year in 1994 (McKeand et al. 1995), after the peak of balsam woolly adelgid mortality (Dull et al. 1988). Cones were harvested from a range of elevations on 17 mountains across the six major populations; most cones were taken along roads and major trails so that as many trees as possible could be sampled and were spaced at least $50 \mathrm{~m}$ apart to reduce the chance of collecting from half-sibling trees. These seed lots were tested for their germination rate and placed in cold storage. Of the 302 foliage samples used in this study, 180 were collected in 2002 from 6-year-old saplings in a rangewide provenance test of Fraser fir, while 122 were collected in 2004 from 6-month-old greenhouse-grown seedlings. Microsatellite population genetic statistics were later compared between greenhousegrown samples and provenance test samples to assess whether the levels of heterozygosity in the groups were affected by life stage, as has been detected in allozymes (Bush and Smouse 1992). An additional 11 subalpine fir (Abies lasiocarpa (Hook.) Nutt.) seedlings from British Columbia, grown from seed provided by the National Tree Seed Centre of Canada, represented an outgroup for the construction of neighbor-joining trees. Genomic DNA was extracted from the foliage samples using DNeasy Plant Mini Kits (Qiagen, Chatsworth, California).

\section{Microsatellite analysis}

The 11 microsatellite markers included in this study were developed from a Fraser fir genomic library enriched for microsatellite sequences (Josserand et al. 2006). Polymerase chain reaction (PCR) amplification was performed in $12 \mu \mathrm{L}$ reaction volumes containing $10 \mathrm{ng}$ of genomic DNA, $1.25 \mu \mathrm{mol} / \mathrm{L}$ of each forward and reverse primer, $0.625 \mathrm{mmol} / \mathrm{L}$ dNTPs, $1 \times$ Taq buffer $\left(2.0 \mathrm{mmol} / \mathrm{L} \mathrm{MgCl}_{2}\right.$, $10 \mathrm{mmol} / \mathrm{L}$ Tris-HCl, $50 \mathrm{mmol} / \mathrm{L} \mathrm{KCl}), 120 \mathrm{mmol} / \mathrm{L}$ $\mathrm{MgCl}_{2}$, and $0.5 \mathrm{U}$ "hot start" Platinum Taq DNA polymerase (Invitrogen Corp., Carlsbad, California). The PCRs were completed using the following touchdown protocol on PTC100 thermal cyclers (MJ Research, Watertown, Massachusetts): $2 \mathrm{~min}$ at $94{ }^{\circ} \mathrm{C}$ followed by 20 cycles of $30 \mathrm{~s}$ at $94{ }^{\circ} \mathrm{C}, 30 \mathrm{~s}$ at $X$, and $30 \mathrm{~s}$ at $72{ }^{\circ} \mathrm{C}$, where $X=65^{\circ} \mathrm{C}$ in the first cycle decreasing by $0.5{ }^{\circ} \mathrm{C}$ every cycle thereafter, followed by 15 cycles of $30 \mathrm{~s}$ at $92{ }^{\circ} \mathrm{C}$, $30 \mathrm{~s}$ at $55^{\circ} \mathrm{C}$, and $1 \mathrm{~min}$ at $72{ }^{\circ} \mathrm{C}$ followed by a $15 \mathrm{~min}$ extension at $72{ }^{\circ} \mathrm{C}$ and an indefinite hold at $4{ }^{\circ} \mathrm{C}$. The primer pairs were multiplexed during PCR, with all the forward primers $5^{\prime}$-end labeled with different fluorophores (6-FAM, VIC, PET, or NED) to avoid the amplification of different loci with similar lengths using the same labeled primers.

The resulting PCR products were purified using Performa DTR V3 96-Well Short Plates (Edge BioSystems, Gaithers-

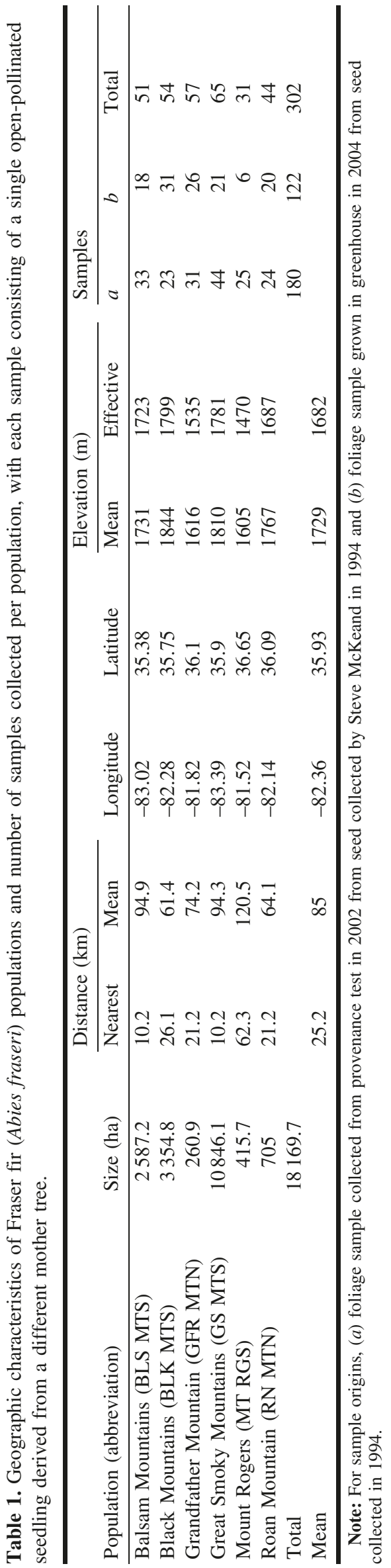

(C) 2008 NRC Canada 
burg, Maryland) and then separated on an ABI 3700 genetic analyzer (Applied Biosystems, Foster City, California) as recommended by the manufacturer. Peaks were sized (base pairs) and binned, and alleles were called, with Genotyper software (Applied Biosystems), using GS(500-250)LIZ as an internal size standard for each sample. To test the efficacy of PCR multiplexing, sets of primer pairs were tested with the same set of 23 samples in both individual marker and multiplex marker runs. The same alleles for each locus were observed whether the primer pair was run individually or in a multiplex set.

\section{Spatial analysis}

ArcGIS 8.1 (ESRI 2001) was used to determine the area of each Fraser fir population and to measure the pairwise geographical distances between population edges (Table 1). The spatial extent of each population was determined with a digital elevation model using areas above $1550 \mathrm{~m}$ within the Southern Appalachian Assessment's red spruce-Fraser fir forest data layer (Hermann 1996).

The interaction of elevation and latitude plays an important role in influencing the climatic conditions that determine the distribution of the Fraser fir-red spruce forest type in the Appalachian Mountains (Cogbill and White 1991). In the absence of temperature and precipitation data available at small scales, we calculated a measure of effective elevation $\left(E_{\mathrm{E}}\right)$ for each sample using our coordinate data for each mother tree. This value reflects the finding by Cogbill and White (1991) that the Appalachian spruce - fir/ deciduous forest ecotone elevation decreases by $100 \mathrm{~m}$ for each degree of latitude and was calculated as

$$
E_{\mathrm{E}}=E_{\mathrm{O}}-(100) \Delta L
$$

where $E_{\mathrm{O}}$ was the original elevation in metres of a mother tree and $\Delta L$ was the difference in latitude between that mother tree and the latitude of the southernmost mother tree in the analysis $\left(35.2983^{\circ} \mathrm{N}, 1621.5 \mathrm{~m}\right.$ in the Balsam Mountains). Effective elevation, therefore, is the elevation of each Fraser fir mother tree if it were located at $35.2983^{\circ} \mathrm{N}$ based on the assumption that a consistent change in environmental conditions occurs with increases in latitude and elevation.

\section{Data analyses}

FSTAT v. 2.9.3.2 (Goudet 1995) tested linkage disequilibrium among all pairs of loci and calculated the Weir and Cockerham (1984) within-population inbreeding coefficient $\left(F_{\mathrm{IS}}\right)$ and among-population divergence $\left(F_{\mathrm{ST}}\right)$. FSTAT also was used to generate basic population-level measures of genetic diversity, including allelic diversity $(A)$ and mean allelic richness $\left(A_{R}\right)$. Genepop (Raymond and Rousset 1995) conducted exact tests for Hardy-Weinberg equilibrium for each locus and population and estimated interpopulation gene flow $(\mathrm{Nm})$ using the private allele method (Barton and Slatkin 1986) corrected for sample size, both for all populations and for all pairs of populations. PopGene32 (Yeh et al. 2000) computed observed heterozygosity $\left(H_{\mathrm{O}}\right)$ and expected heterozygosity $\left(H_{\mathrm{E}}\right)$ given Hardy-Weinberg equilibrium. Micro-Checker 2.2.3 (van Oosterhout et al. 2004) estimated null allele frequencies at each locus. We utilized the MicroChecker module that adjusts null allele frequencies to ac- count for the expected presence of inbreeding (van Oosterhout et al. 2006) using an $F_{\text {IS }}$ estimate of 0.1028 from a previous Fraser fir allozyme study (Ross 1988). For the two loci for which this method could not find a solution (AfSIO9 and AfSI14), we estimated null frequencies using the approach of Brookfield (1996). To estimate the genetic distance between populations, we computed population $F_{\mathrm{ST}}$ values between each pair of populations using FSTAT (Goudet 1995) as well as chord genetic distance $\left(D_{\mathrm{C}}\right)$ (Cavalli-Sforza and Edwards 1967) using the GENDIST component of PHYLIP 3.6 (Felsenstein 2005). Chord distance is based on a geometric model that does not require assumptions about whether microsatellites mutate under the infinite alleles model or the stepwise mutational model (Takezaki and Nei 1996) and is less biased by null alleles than Nei's genetic distance in microsatellite analyses (Chapuis and Estoup 2007). The Isolation by Distance 1.5 (IBD) software package (Bohonak 2002) quantified the relationships between these genetic differences and the geographic characteristics of population isolation and latitude by using a Mantel test to regress all pairwise genetic distances with each of their corresponding geographic matrices. Additionally, Pearson correlation coefficients were calculated between population genetic data and geographic characteristics using the PROC CORR procedure in SAS 9.1 (SAS Institute Inc. 2003). Mean germination rates of the open-pollinated seed lots used from each population were also tested for correlations with population genetic data and geographic characteristics. A neighbor-joining tree was constructed using the SEQBOOT, GENDIST, NEIGHBOR, and CONSENSE components of PHYLIP 3.6 (Felsenstein 2005), computed from population allelic frequencies using chord distance $D_{\mathrm{C}}$. Confidence estimates associated with the topology of the tree were assigned based on 1000 bootstrap replicates.

\section{Results}

Because the samples used in this study were all grown from seed, the inadvertent selection of genotypes under controlled growth conditions could create a potential source of bias compared with mature trees grown in natural stands. In fact, we would expect this to be the case, since Ross (1988) found considerable genetic differences between parent and offspring Fraser fir trees in an allozyme study. We determined, however, that such bias is unlikely to exist between the 6-month-old greenhouse samples and the 6-year-old provenance test samples included in this study, both of which were grown from seed collected in 1994. A $t$ test found no difference in the mean germination rates of the two groups (30\% for the greenhouse-grown samples and $32.7 \%$ for the provenance test samples). To test for potential genetic differences between the groups caused by differential selection forces, we compared a subset of 32 samples from each group, paired by population and elevation between groups to control for the effects of provenance and elevation of origin. The greenhouse and provenance test results were not statistically different for mean $H_{\mathrm{O}}(0.347$ and 0.351 , respectively), $F_{\text {IS }}(0.235$ and 0.232$)$, and mean alleles per locus (4.64 and 4.45). Additionally, the $F_{\mathrm{ST}}$ between the groups was not significantly different from 0 , 
Table 2. Relative measurements of genetic differentiation and estimates of gene flow among Fraser fir populations using eight nuclear microsatellite loci.

\begin{tabular}{lrlllll}
\hline Locus & \multicolumn{1}{c}{$A$} & \multicolumn{1}{l}{$F_{\text {IS }}$} & $H_{\mathrm{O}}$ & \multicolumn{1}{l}{$H_{\mathrm{E}}$} & HWE & $\begin{array}{l}\text { Proportion of } \\
\text { null alleles }\end{array}$ \\
\hline AfSI02 & 10 & $0.204(0.028)$ & 0.385 & 0.489 & $* * * *$ & 0.05 \\
AfSI03 & 4 & $0.171(0.058)$ & 0.422 & 0.507 & $* *$ & 0.031 \\
AfSIO6 & 14 & $0.072(0.024)$ & 0.758 & 0.823 & $* *$ & -0.017 \\
AfSI08 & 16 & $0.324(0.052)$ & 0.438 & 0.65 & $* * * *$ & 0.17 \\
AfSI09 & 5 & $0.479(0.206)$ & 0.017 & 0.031 & $* * *$ & 0.013 \\
AfSI14 & 10 & $0.598(0.051)$ & 0.042 & 0.107 & $* * * *$ & 0.059 \\
AfSI16 & 10 & $0.312(0.067)$ & 0.489 & 0.722 & $* * * *$ & 0.138 \\
AfSI20 & 5 & $0.123(0.09)$ & 0.18 & 0.207 & $* * *$ & 0.022 \\
Total & & $0.223(0.056)$ & & & $* * * *$ & \\
Mean & 9.25 & 0.285 & 0.341 & 0.442 & & 0.058 \\
\hline
\end{tabular}

Note: $A$, alleles per locus; $F_{\mathrm{IS}}$, inbreeding coefficient; $H_{\mathrm{O}}$ and $H_{\mathrm{E}}$ observed and expected heterozygosity, respectively; HWE, Hardy-Weinberg exact test of heterozygote deficiency, with $* * p<0.01$, $* * * p<0.001$, and $* * * * p<0.0001$. Loci AfSIO4 and AfSI05 were omitted from analysis due to high proportions of null alleles $(0.277$ and 0.32 , respectively). Locus AfSIII was omitted from further analysis due to its significant $(p<0.05)$ linkage disequilibrium with AfSIO3 and its higher proportion of null alleles $(0.11$ versus 0.031$)$. Standard error is given in parentheses. Null alleles were estimated using Micro-Checker (van Oosterhout et al. 2004, 2006).

as determined by a jackknife test across loci. All samples were subsequently included in the analyses.

Two loci, AfSIO4 and AfSI05, were eliminated from further analysis because of a high estimated proportion of null alleles $(>0.2)$. Null alleles can occur as a result of priming site mutations or large or small allele dropout (DeWoody et al. 2006), inflating the number of homozygous genotypes and resulting in overestimated inbreeding values and genotype frequencies (Amos 2006). Additionally, significant linkage disequilibrium was found between two loci, AfSIO3 and AfSI11, with $p<0.05$ after Bonferroni corrections. AfSIII was removed from further analyses because its proportion of null alleles (0.11) was higher than that of AfSIO3 (0.031).

\section{Microsatellite variation within Fraser fir}

An exact test for Hardy-Weinberg equilibrium indicated a significant deficit of heterozygotes for each locus and over all loci (Table 2). Observed heterozygosity $H_{\mathrm{O}}$, across the loci for all samples (0.341) was considerably lower than the mean expected heterozygosity under Hardy-Weinberg expectations (0.442). Similarly, all of the Fraser fir populations had a highly significant deficit of heterozygotes (Table 3 ). The significantly positive $F_{\text {IS }}$ inbreeding coefficient for Fraser fir (0.223) was indicative of a considerable deficit of heterozygotes in the species and the likely presence of inbreeding (Table 2). Similarly, each of the Fraser fir populations also had a significantly positive $F_{\text {IS }}$ value (Table 3).

Among-population divergence $F_{\mathrm{ST}}$ averaged across the loci was low (0.004), indicating a small proportion of genetic variation occurred between populations. The value of $F_{\mathrm{ST}}$, however, was significantly different from 0 after jackknifing over loci. The predicted number of interpopulation migrants per generation, $\mathrm{Nm}$, was 9.77 using the private allele method of Barton and Slatkin (1986).

\section{Population genetic variation and differentiation}

The Great Smoky Mountain and Grandfather Mountain populations had the most alleles per locus (5.88) followed by the Balsam Mountain and Roan Mountain populations (5.75). The Balsam Mountain and Grandfather Mountain populations had the greatest allelic richness followed by Mount Rogers. Grandfather Mountain and the Great Smoky Mountains had the most private alleles and the highest mean $\mathrm{Nm}$ value across their pairwise relationships with other populations (Table 3).

The most isolated population, Mount Rogers, had relatively high allelic richness but was also the most inbred (highest $F_{\text {IS }}$ ). It also had the most significant pairwise $F_{\text {ST }}$ relationships with the other populations (four, compared with one or none for the others) and the lowest mean pairwise $\mathrm{Nm}$ with the other populations (Tables 3 and 4). Meanwhile, the Black Mountain population, which is the least isolated population based on its mean distance to the other populations, was the least inbred and possessed no private alleles.

The consensus dendrogram of Fraser fir populations based on chord distance $D_{\mathrm{C}}$ depicted a well-supported clade containing the three southernmost populations along with Grandfather Mountain (Fig. 2). Two northern populations, Roan Mountain and Mount Rogers, were increasingly distantly related to this cluster, with Mount Rogers strongly supported as the most differentiated population.

\section{Relationship between genetic and geographic characteristics}

No correlations existed between population area or mean effective elevation and any genetic characteristic. Population isolation, as measured by a population's distance to the nearest population, was correlated with each population's number of significant pairwise $F_{\mathrm{ST}}$ differences $(r=0.875$, $p=0.022$ ), suggesting that more isolated populations were more likely to be genetically differentiated. Mean geographic distance to all other populations, another measure of isolation, was nearly significantly correlated with number of significant pairwise $F_{\mathrm{ST}}$ differences $(r=0.761, p=$ $0.079)$. Neither inbreeding coefficient nor observed hetero- 
Table 3. Measures of genetic variation for each of six Fraser fir populations based on eight nuclear microsatellite loci, including the number of pairwise $F_{\mathrm{ST}}$ values with other populations statistically different from 0 and mean pairwise $\mathrm{Nm}$ values with all other populations.

\begin{tabular}{lllllllllll}
\hline & & & & & & \multicolumn{3}{c}{ Significant } \\
Population & $n$ & $A$ & $A_{\mathrm{R}}$ & $A_{\mathrm{P}}$ & $H_{\mathrm{O}}$ & $H_{\mathrm{E}}$ & $F_{\mathrm{IS}}$ & HWE & $F_{\mathrm{ST}}$ & Mean $N m$ \\
\hline BLS MTS & 51 & 5.75 & 4.6 & 5 & 0.334 & 0.444 & $0.251^{*}$ & $* * * *$ & 1 & 5.9 \\
BLK MTS & 54 & 4.75 & 4.04 & 0 & 0.348 & 0.42 & $0.172^{*}$ & $* * * *$ & 1 & 5.56 \\
GFR MTN & 57 & 5.88 & 4.5 & 6 & 0.361 & 0.457 & $0.213^{*}$ & $* * * *$ & 0 & 7.05 \\
GS MTS & 65 & 5.88 & 4.28 & 6 & 0.336 & 0.428 & $0.218^{*}$ & $* * * *$ & 1 & 7.22 \\
MT RGS & 31 & 5.13 & 4.49 & 4 & 0.343 & 0.468 & $0.271^{*}$ & $* * * *$ & 4 & 4.17 \\
RN MTN & 44 & 5.75 & 4.46 & 4 & 0.323 & 0.433 & $0.258^{*}$ & $* * * *$ & 1 & 5.12 \\
Mean & 50.33 & 5.52 & 4.4 & 4.17 & 0.341 & 0.442 & 0.231 & $* * * *$ & 1.33 & 5.84 \\
\hline
\end{tabular}

Note: $A$, mean alleles per locus; $A_{\mathrm{R}}$, mean allelic richness; $A_{\mathrm{P}}$, private (unique) alleles; $H_{\mathrm{O}}$ and $H_{\mathrm{E}}$ mean observed and expected heterozygosity, respectively; $F_{\mathrm{IS}}$, mean fixation index, with $p$ value based on 1400 randomizations; HWE, Hardy-Weinberg exact test of heterozygote deficiency; $* p<0.05$ and $* * * * p<0.0001$. See Table 1 population for abbreviations.

Table 4. Pairwise differences among Fraser fir populations based on eight nuclear microsatellite loci.

\begin{tabular}{lccclll}
\hline Population & BLS MTS & BLK MTS & GFR MTN & GS MTS & MT RGS & RN MTN \\
\hline BLS MTS & & 5.35 & 7.55 & 7.53 & 4.00 & 5.05 \\
BLK MTS & -0.001 & & 5.88 & 8.2 & 2.67 & 5.71 \\
GFR MTN & -0.001 & 0.001 & & 9.01 & 5.88 & 6.94 \\
GS MTS & -0.003 & -0.003 & -0.002 & & 5.89 & 5.47 \\
MT RGS & $0.026^{*}$ & $0.019^{*}$ & 0.010 & $0.017^{*}$ & & 2.41 \\
RN MTN & -0.003 & -0.006 & 0.003 & 0.006 & $0.022^{*}$ & \\
\hline
\end{tabular}

Note: Above the diagonal: pairwise interpopulation gene flow $(\mathrm{Nm})$ from Genepop (Raymond and Rousset 1995) using the private allele method (Barton and Slatkin 1986); below the diagonal: pairwise $F_{\mathrm{ST}}$ estimates from FSTAT (Goudet 1995). *Significantly different from 0 jackknifing over loci. See Table 1 for abbreviations.

zygosity was correlated with any geographic characteristic. No correlation existed between the mean germination rate for populations and any genetic statistic or geographic characteristic.

A Mantel test demonstrated that pairwise $F_{\text {ST }}$ values were significantly correlated with pairwise interpopulation geographic distances $(r=0.579, p=0.024)$ and latitude differences $(r=0.649, p=0.045)$. Chord distance $D_{\mathrm{C}}$ and pairwise $\mathrm{Nm}$ were not correlated with any geographic characteristic. Pairwise geographic distance and latitude differences were correlated $(r=0.651, p=0.025)$, confounding causal explanations for genetic patterns. No correlation existed between population area or sample size and any pairwise genetic or geographic difference.

\section{Discussion}

The Fraser fir microsatellite results suggest that the species exists as a genetically well-mixed set of populations, even by the standards of other conifers. The low level of genetic differentiation among Fraser fir populations $\left(F_{\mathrm{ST}}=\right.$ 0.004) is slightly smaller than a five-allozyme study by Ross (1988), which found a mean $F_{\mathrm{ST}}$ of 0.013 for adult trees and 0.016 for progeny. Populations of outcrossing gymnosperm and long-lived perennial plant species, such as Fraser fir, are often poorly differentiated (Hamrick and Godt 1996). At the same time, recent nuclear microsatellite studies in other conifers have generally yielded considerably higher levels of population differentiation than in Fraser fir, including Picea asperata Mast. $\left(F_{\mathrm{ST}}=0.223\right)$ (Wang et al. $2005)$, Pinus radiata D. Don $\left(F_{\mathrm{ST}}=0.14\right)$ (Karhu et al. 2006), Pinus taeda L. $\left(F_{\mathrm{ST}}=0.223\right)$ (Al-Rabab'ah and Wil- liams 2002), and Pinus resinosa Ait. $\left(F_{\mathrm{ST}}=0.223\right)$ (Boys et al. 2005). The endangered fir species Abies ziyuanensis L.K. Fu et S.L. Mo, which exists on a handful of mountains in southern China, also has a considerably higher microsatellite $F_{\text {ST }}$ value of 0.25 (Tang et al. 2008).

The statistically significant heterozygote deficiencies and significantly positive inbreeding coefficients detected in Fraser fir and all its populations (Tables 2 and 3) suggest that this species may be genetically impoverished relative to many other conifers, especially those with larger and more continuous distributions. Its inbreeding coefficient $F_{\text {IS }}$ (0.223), for example, is higher than the 0.154 inbreeding coefficient found in an allozyme study of the closely allied and widely distributed Abies balsamea (L.) Mill. (Shea and Furnier 2002). The Fraser fir microsatellite analysis also found a relatively low mean observed heterozygosity $\left(H_{\mathrm{o}}=0.341\right)$ compared with recent microsatellite studies in other conifers (Al-Rabab'ah and Williams 2002; Wang et al. 2005), although Fraser fir's relatively low mean $H_{\mathrm{o}}$ was higher than that observed in Pinus resinosa (0.185) (Boys et al. 2005). It is important to note, however, that the Fraser fir heterozygosity and inbreeding results may be affected at least in part by the age class of trees included in the analysis. Several allozyme studies have detected increasing heterozygosity with age (reviewed in Bush and Smouse (1992)), apparently the result of selection over time against inbred individuals. Ross (1988), in fact, found this to be the case in her allozyme study of Fraser fir.

The consistently significant deficiency of heterozygotes across loci and populations (Tables 2 and 3), potentially exacerbated by the life stage of the trees included in the anal- 
Fig. 2. Neighbor-joining consensus dendrogram depicting chord genetic distances $\left(D_{C}\right)$ (Cavalli-Sforza and Edwards 1967) among the six populations of Fraser fir, with subalpine fir from British Columbia (BC), Canada, as an outgroup. The values represent percent bootstrap support for the nodes over 1000 replicates. Nodes with greater than 50\% bootstrap support are considered well supported. See Fig. 1 for abbreviations.

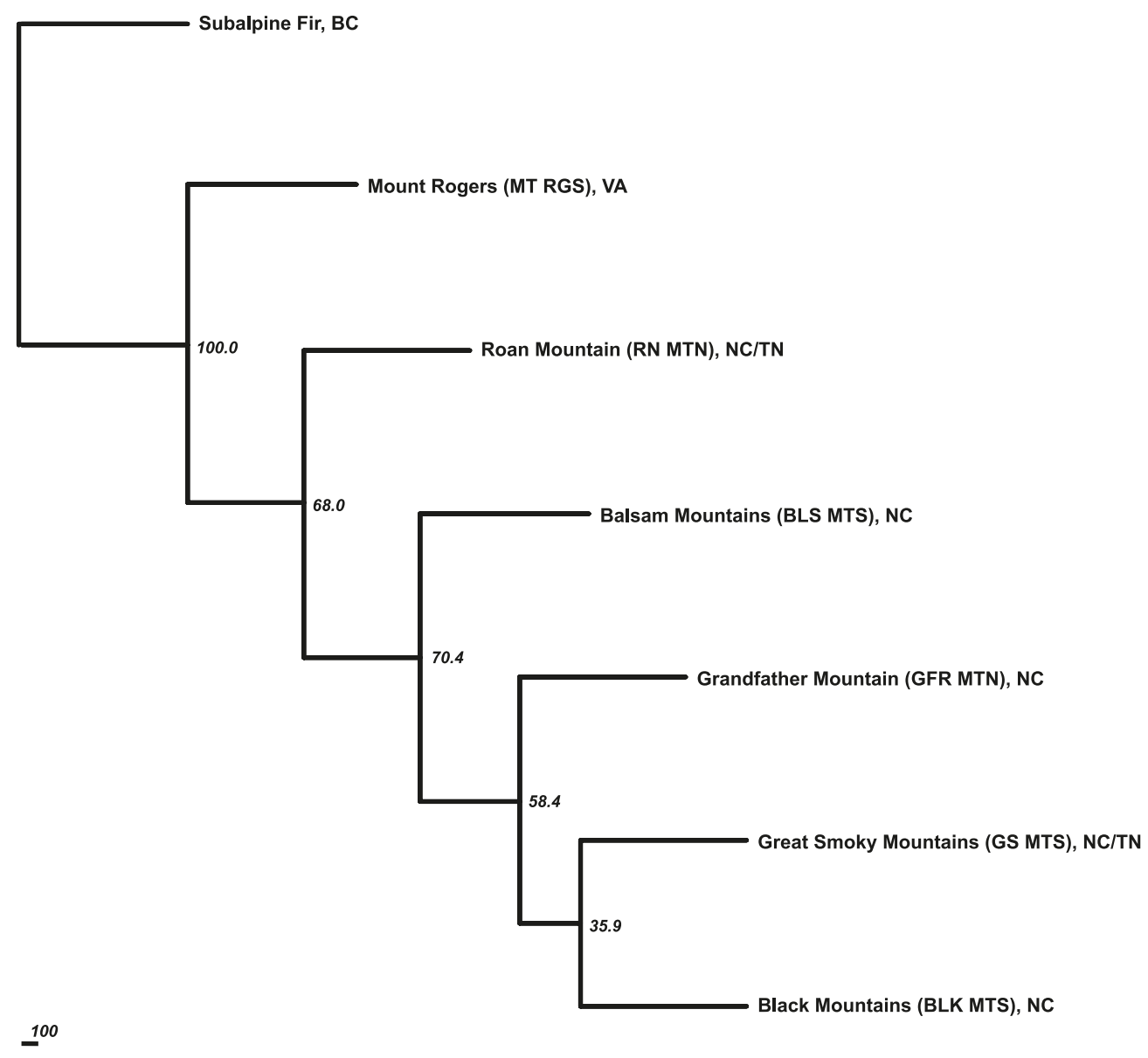

ysis, appears to argue in favor of a population-level explanation that the species and its populations are out of HardyWeinberg equilibrium, rather than an overriding effect of null alleles (Amos 2006). Of particular interest are the loci with low estimated frequencies of null alleles (AfSIO2, AfSI03, AfSI06, AfSI09, and AfSI20) that also were highly significant in an exact test for heterozygote deficiency (Table 2). In addition to inbreeding, a Wahlund effect caused by spatial substructuring of within-population demes would also explain the excess homozygosity in Fraser fir. An isozyme study of the Mount Rogers population of Fraser fir, however, detected none of the microgeographic substructuring that would likely result in a Wahlund effect (Diebel and Feret 1991).

\section{Factors influencing Fraser fir genetic architecture}

Fraser fir population area was not correlated with any measure of genetic diversity, suggesting that the post-Pleistocene fragmentation of the species did not result in smaller populations suffering differentially from the detrimental genetic effects often associated with small population size, including genetic drift. In fact, the smallest Fraser fir population, Grandfather Mountain, exhibited among the highest values of some measures of genetic variation, including alleles per locus and number of private alleles (Table 3).
Population latitude and isolation appear to be more important factors than population area in explaining the genetic structure of Fraser fir populations. For example, the Mantel test results indicated that population pairwise latitudinal differences and distance were important geographic characteristics in explaining genetic differentiation among populations, while area was not correlated with any genetic characteristic of populations. Additionally, the dendrogram of $D_{\mathrm{C}}$ genetic distances suggests that southern populations are generally more similar to each other than they are to northern populations (Fig. 2). This is consistent with an isozyme study that included three Fraser fir provenances with nine balsam fir provenances, which found two southern provenances, Clingman's Dome in the Great Smoky Mountains and Mount Mitchell in the Black Mountains, clustering separately from the northern Mount Rogers population (Jacobs et al. 1984).

Interpopulation gene exchange and post-Pleistocene history are possible explanations for this pattern of genetic architecture. The first of these, interpopulation gene flow, may reduce differentiation among populations by countering the local disruptive effects of inbreeding and genetic drift (Hamrick and Nason 2000). While Fraser fir seed and pollen are both dispersed by wind, the long-distance exchange of fir genes among populations is more likely to occur by pol- 
len movement (Ziegenhagen et al. 2004), especially given that Fraser fir populations are 10-175 km apart.

In the current study of Fraser fir, the estimate of specieswide immigrants per generation $(\mathrm{Nm}=9.77)$ points to the possible existence of considerable among-population genetic exchange. A Mantel test did not find any significant correlation between matrices of pairwise $\mathrm{Nm}$ values and pairwise population geographic distance or latitude differences. Such a correlation might be expected with long-distance pollen exchange between populations, since pollen-mediated gene exchange in forest trees exhibits a high probability of dispersal at local scales that decreases rapidly with distance from the pollen source (Ellstrand 1992). At the same time, pairwise $F_{\mathrm{ST}}$ among populations was correlated with both pairwise geographic distance and latitudinal differences, a pattern that could be explained by interpopulation gene exchange. Additionally, the most central population (the Black Mountains) had the fewest private alleles and was among the least inbred (Table 3), suggesting the possibility of long-distance gene exchange with populations to the north and south.

Genetic variation in plant populations is structured not only by contemporary genetic exchange but by historical relationships as well. The relationship between latitude and population genetic characteristics in Fraser fir may reflect how the species responded to the most recent warming period in the 41000-year cycles of ice sheet advancement and retreat that have occurred since the beginning of the Quaternary, 2.4 million years ago (Hewitt 2000). By approximately 7000 years ago, fir had retreated from its Pleistocene refuge in the southeastern United States, its main distribution having separated from Fraser fir in the Southern Appalachians and shifted north into Canada, New England, and the Northern Appalachians, where it is now classified as Abies balsamea (Delcourt and Delcourt 1987). While Fraser fir remains closely related to this northern species, a chloroplast microsatellite analysis determined that Fraser fir was differentiated enough to warrant being considered genetically distinct (Clark et al. 2000).

During such shifts in the distribution of a species, the retreating rear edge of the range is expected to suffer shrinkage, dissection, and extinction, with the last surviving populations being severely bottlenecked (Hewitt 2000). This may have been countered to some degree in Fraser fir by the facts that populations are progressively isolated from south to north $(r=0.832, p=0.04)$, that the highest elevation populations occur at the southern end of the Fraser fir range, and that some of the largest populations are clustered at the southern end of the species' range. Alternatively, the greater number of private alleles found in southernmost Fraser fir populations may suggest that these populations are nearer the location of the species' Pleistocene refuge, since areas closer to a refuge are expected to have greater genetic variation than areas colonized later (Hewitt 1996). An allozyme study of another conifer species in the Southern Appalachians, eastern hemlock (Tsuga canadensis (L.) Carr.), found such a pattern, with populations further south exhibiting greater allelic diversity and polymorphism (Potter et al. 2008).

It is also possible that the genetic structure of Fraser fir populations was affected by a mid-Holocene period of higher-than-current warmth and aridity, which occurred approximately 8700-5000 years ago (Delcourt and Delcourt 1998). This hypsithermal period may have eliminated Fraser fir from lower-elevation summits (Whittaker 1956) and reduced the size of remaining populations, creating a bottleneck that resulted in the relatively high inbreeding and low heterozygosity statistics detected in the current study.

\section{Implications for conservation}

Conservation of Fraser fir's genetic composition may be necessary given the threats to its persistence from the infestation of an exotic pest and from global climate change. It is listed in North Carolina as a significantly rare species, as a species of concern federally, and as a species imperiled and vulnerable to extinction globally (Franklin and Finnegan 2004). The balsam woolly adelgid (Adelges piceae), an aphid-like insect from Europe, has inflicted severe mortality on old-growth Fraser fir forest during the last 50 years (Dull et al. 1988), killing mature trees within 2-9 years of infestation (Hollingsworth and Hain 1991). Stands have been able to regenerate with vigorous and numerous offspring (DeSelm and Boner 1984; Witter and Ragenovich 1986) that have recently begun to reenter the overstory (Smith and Nicholas 2000). Additionally, Delcourt and Delcourt (1998) predicted the elimination of Southern Appalachian Fraser fir-red spruce forest with a global mean temperature increase of $3{ }^{\circ} \mathrm{C}$ caused by greenhouse-effect warming.

The results of this microsatellite study indicate that, while small compared with other conifer species, differences among Fraser fir populations are important enough to warrant a wide sampling of populations to adequately conserve the genetic base of the species. These findings are consistent with significant between-population differences in adaptive traits among populations found during common garden experiments (Arnold et al. 1994; Emerson et al. 2006, 2008) and significant between-population differences in allozyme frequencies (Ross 1988). The current analysis shows that the small Grandfather Mountain population, for example, contains a high proportion of allelic richness and private alleles, while the isolated Mount Rogers population was significantly differentiated from the other populations. In both cases, the results may indicate the presence within these populations of greater variation in functional genes, which could translate into more potentially novel combinations of alleles and, therefore, into traits with adaptive significance. Mount Rogers may be of particular interest for gene conservation and tree breeding efforts, if the relatively low adelgid mortality there is the result of pest resistance traits not present in the other populations (Rheinhardt 1984). Guided in part on the results of this microsatellite marker study, a range-wide collection of seed from each Fraser fir population was conducted in 2007, supplementing the previous 1994 collection.

\section{Acknowledgements}

The authors thank Valerie Hipkins, Jennifer DeWoody, Jenny Xiang, and Michael Purugganan and three anonymous reviewers for their helpful comments, Steve McKeand for coordinating the 1994 range-wide collection of Fraser fir seed, AnneMargaret Braham for assistance in growing the Fraser fir seedlings, and Jianfeng Li for laboratory help and 
for collecting foliage samples from the provenance test sites. Additionally, we appreciate the laboratory assistance of Regina Ali and Heather Aycock at the Genome Research Laboratory at North Carolina State University. We also thank Bernard Daigle of the National Tree Seed Centre at Natural Resources Canada for providing the subalpine fir seed. This work was supported by the College of Natural Resources, the Christmas Tree Genetics Program, the Department of Forestry and Environmental Resources, and the Graduate School at North Carolina State University.

\section{References}

Al-Rabab'ah, M.A., and Williams, C.G. 2002. Population dynamics of Pinus taeda L. based on nuclear microsatellites. For. Ecol. Manag. 163: 263-271. doi:10.1016/S0378-1127(01)00584-9.

Amos, W. 2006. The hidden value of missing genotypes. Mol. Biol. Evol. 23: 1995-1996. doi:10.1093/molbev/msl078. PMID:16891378.

Arnold, R.J., Jett, J.B., and McKeand, S.E. 1994. Natural variation and genetic parameters in Fraser fir for growth and Christmas tree traits. Can. J. For. Res. 24: 1480-1486.

Barton, N.H., and Slatkin, M. 1986. A quasi-equilibrium theory of the distribution of rare alleles in a subdivided population. Heredity, 56: 409-415. doi:10.1038/hdy.1986.63. PMID:3733460.

Bohonak, A.J. 2002. IBD (isolation by distance): a program for analyses of isolation by distance. J. Hered. 93: 153-154. doi:10. 1093/jhered/93.2.153. PMID:12140277.

Boys, J., Cherry, M., and Dayanandan, S. 2005. Microsatellite analysis reveals genetically distinct populations of red pine (Pinus resinosa Pinaceae). Am. J. Bot. 92: 833-841. doi:10.3732/ajb. 92.5.833.

Brookfield, J.F.Y. 1996. A simple new method for estimating null allele frequency from heterozygote deficiency. Mol. Ecol. 5: 453455. doi:10.1111/j.1365-294X.1996.tb00336.x. PMID:8688964.

Bush, R.M., and Smouse, P.E. 1992. Evidence for the adaptive significance of allozymes in forest trees. New For. 6: 179-196.

Busing, R.T., White, P.S., and MacKenzie, M.D. 1993. Gradient analysis of old spruce-fir forests of the Great Smoky Mountains circa 1935. Can. J. Bot. 71: 951-958.

Cavalli-Sforza, L.L., and Edwards, A.W.F. 1967. Phylogenetic analysis: models and estimation procedures. Evolution, 21: 550570. doi:10.2307/2406616.

Chapuis, M.P., and Estoup, A. 2007. Microsatellite null alleles and estimation of population differentiation. Mol. Biol. Evol. 24: 621-631. doi:10.1093/molbev/msl191. PMID:17150975.

Clark, C.M., Wentworth, T.R., and O’Malley, D.M. 2000. Genetic discontinuity revealed by chloroplast microsatellites in eastern North American Abies (Pinaceae). Am. J. Bot. 87: 774-782. doi:10.2307/2656885. PMID:10860908.

Cogbill, C.V., and White, P.S. 1991. The latitude-elevation relationship for the spruce-fir forest and treeline along the Appalachian mountain chain. Vegetatio, 94: 153-175. doi:10.1007/ BF00032629.

Delcourt, H.R., and Delcourt, P.A. 1984. Late-Quaternary history of the spruce-fir ecosystem in the Southern Appalachian region. In The Southern Appalachian spruce-fir ecosystem: its biology and threats. Edited by P.S. White. U.S. Department of the Interior, National Park Service, Atlanta, Ga. pp. 22-35.

Delcourt, P.A., and Delcourt, H.R. 1987. Long-term forest dynamics of the temperate zone. Springer-Verlag, New York.

Delcourt, P.A., and Delcourt, H.R. 1998. Paleoecological insights on conservation of biodiversity: a focus on species, ecosystems, and landscapes. Ecol. Appl. 8: 921-934.
DeSelm, H.R., and Boner, R.R. 1984. Understory changes in spruce-fir during the first 16-20 years following the death of fir. In The Southern Appalachian spruce-fir ecosystem: its biology and threats. Edited by P.S. White. U.S. Department of the Interior, National Park Service, Atlanta, Ga. pp. 51-69.

DeWoody, J., Nason, J.D., and Hipkins, V.D. 2006. Mitigating scoring errors in microsatellite data from wild populations. Mol. Ecol. Notes, 6: 951-957. doi:10.1111/j.1471-8286.2006.01449.x.

Diebel, K.E., and Feret, P.P. 1991. Isozyme variation within the Fraser fir (Abies fraseri (Pursh) Poir.) population on Mount Rogers, Virginia: lack of microgeographic differentiation. Silvae Genet. 40: 79-85.

Dull, C.W., Ward, J.D., Brown, H.D., Ryan, G.W., Clerke, W.H., and Uhler, R.J. 1988. Evaluation of spruce and fir mortality in the Southern Appalachian Mountains. U.S. Dep. Agric. For. Serv. Southern Region Protection Rep. R-8-PR-13.

Duminil, J., Fineschi, S., Hampe, A., Jordano, P., Salvini, D., Vendramin, G.G., and Petit, R.J. 2007. Can population genetic structure be predicted from life-history traits? Am. Nat. 169: 662-672. doi:10.1086/513490. PMID:17427136.

Ellstrand, N.C. 1992. Gene flow among seed plant populations. New For. 6: 241-256.

Emerson, J.L., Frampton, J., and McKeand, S.E. 2006. Genetic variation of spring frost damage in 3-year-old Fraser fir Christmas tree plantations. HortScience, 41: 1531-1536.

Emerson, J.L., Frampton, J., and McKeand, S.E. 2008. Genetic variation in early growth and bud production among natural populations of Fraser fir. HortScience, 43: 661-666.

ESRI. 2001. ArcGIS 8.1. Environmental Systems Research Institute Inc., Redlands, Calif.

Felsenstein, J. 2005. PHYLIP (Phylogeny Inference Package). Version 3.6. Department of Genome Sciences, University of Washington, Seattle, Wash.

Franklin, M.A., and Finnegan, J.T. (Editors). 2004. Natural heritage program list of the rare plant species of North Carolina. North Carolina Department of Environment and Natural Resources, North Carolina Natural Heritage Program, Raleigh, N.C..

Gitzendanner, M.A., and Soltis, P.S. 2000. Patterns of genetic variation in rare and widespread plant congeners. Am. J. Bot. 87: 783-792. doi:10.2307/2656886. PMID:10860909.

Godt, M.J.W., and Hamrick, J.L. 2001. Genetic diversity in rare southeastern plants. Nat. Areas J. 21: 61-70.

Goudet, J. 1995. FSTAT. Version 1.2. A computer program to calculate $F$-statistics. J. Hered. 86: 485-486.

Hamrick, J.L., and Godt, M.J.W. 1996. Effects of life history traits on genetic diversity in plant species. Philos. Trans. R. Soc. Lond. Ser. B Biol. Sci. 351: 1291-1298. doi:10.1098/rstb.1996.0112.

Hamrick, J.L., and Nason, J.D. 2000. Gene flow in forest trees. In Forest conservation genetics: principles and practice. Edited by A.G. Young, D. Boshier, and T.J. Boyle. CSIRO Publishing, Collingwood, Australia. pp. 81-90.

Hermann, K.A. (Editor). 1996. The Southern Appalachian Assessment GIS database CD ROM set. The Southern Appalachian Man and the Biosphere Program, Norris, Tenn.

Hewitt, G.M. 1996. Some genetic consequences of ice ages, and their role in divergence and speciation. Biol. J. Linn. Soc. 58: 247-276.

Hewitt, G.M. 2000. The genetic legacy of the Quaternary ice ages. Nature (Lond.), 405: 907-913. doi:10.1038/35016000. PMID:10879524.

Hollingsworth, R.G., and Hain, F.P. 1991. Balsam woolly adelgid (Homoptera, Adelgidae) and spruce-fir decline in the Southern Appalachians: assessing pest relevance in a damaged ecosystem. Fla. Entomol. 74: 179-187. doi:10.2307/3495294. 
Jacobs, B., Werth, C.R., and Gutman, S.I. 1984. Genetic relationships in Abies (fir) of eastern United States: an electrophoretic study. Can. J. Bot. 62: 609-616.

Josserand, S., Potter, K.M., Johnson, G., Bowen, J.A., Frampton, J., and Nelson, C.D. 2006. Isolation and characterization of microsatellite markers in Fraser fir (Abies fraseri). Mol. Ecol. Notes, 6: 65-68. doi:10.1111/j.1471-8286.2005.01138.x.

Karhu, A., Vogl, C., Moran, G.F., Bell, J.C., and Savolainen, O. 2006. Analysis of microsatellite variation in Pinus radiata reveals effects of genetic drift but no recent bottlenecks. J. Evol. Biol. 19: 167-175. doi:10.1111/j.1420-9101.2005.00982.x. PMID:16405588.

McKeand, S.E., Bridgwater, F.E., McKinley, C.R., Jett, J.B., and Arnold, R.J. 1995. Seed collection from natural stands of Fraser fir and plans for breeding and genetics research at NCSU. Limbs \& Needles, 22: 4, 6-7.

Potter, K.M., Dvorak, W.S., Crane, B.S., Hipkins, V.D., Jetton, R.M., Whittier, W.A., and Rhea, R. 2008. Allozyme variation and recent evolutionary history of eastern hemlock (Tsuga canadensis) in the southeastern United States. New For. 35: 131-145.

Raymond, M., and Rousset, F. 1995. Genepop. Version-1.2. Population genetics software for exact tests and ecumenicism. J. Hered. 86: 248-249.

Rheinhardt, R.D. 1984. Comparative study of composition and distribution patterns of subalpine forests in the Balsam Mountains of southwest Virginia and the Great Smoky Mountains. Bull. Torrey Bot. Club, 111: 489-493. doi:10.2307/2995900.

Ross, R.K. 1988. Patterns of allelic variation in natural populations of Abies fraseri. Ph.D. thesis, Department of Forestry, North Carolina State University, Raleigh, N.C.

SAS Institute Inc. 2003. The SAS System for Windows. Version 9.1. Cary, North Carolina.

Shea, K.L., and Furnier, G.R. 2002. Genetic variation and population structure in central and isolated populations of balsam fir, Abies balsamea (Pinaceae). Am. J. Bot. 89: 783-791. doi:10. 3732/ajb.89.5.783.

Smith, G.F., and Nicholas, N.S. 2000. Size- and age-class distributions of Fraser fir following balsam woolly adelgid infestation. Can. J. For. Res. 30: 948-957. doi:10.1139/cjfr-30-6-948.

Takezaki, N., and Nei, M. 1996. Genetic distances and reconstruction of phylogenetic trees from microsatellite DNA. Genetics, 144: 389-399. PMID:8878702.
Tang, S., Dai, W., Li, M., Zhang, Y., Geng, Y., Wang, L., and Zhong, Y. 2008. Genetic diversity of relictual and endangered plant Abies ziyuanensis (Pinaceae) revealed by AFLP and SSR markers. Genetica, 133: 21-30.

van Oosterhout, C., Hutchinson, W.F., Wills, D.P.M., and Shipley, P. 2004. Micro-Checker: Software for identifying and correcting genotyping errors in microsatellite data. Mol. Ecol. Notes, 4: 535-538. doi:10.1111/j.1471-8286.2004.00684.x.

van Oosterhout, C., Weetman, D., and Hutchinson, W.F. 2006. Estimation and adjustment of microsatellite null alleles in nonequilibrium populations. Mol. Ecol. Notes, 6: 255-256. doi:10. 1111/j.1471-8286.2005.01082.x.

Wang, Y.H., Luo, J.X., Xue, X.M., Korpelainen, H., and Li, C.Y. 2005. Diversity of microsatellite markers in the populations of Picea asperata originating from the mountains of China. Plant Sci. 168: 707-714. doi:10.1016/j.plantsci.2004.10.002.

Weir, B.S., and Cockerham, C.C. 1984. Estimating $F$-statistics for the analysis of population structure. Evolution, 38: 1358-1370. doi: $10.2307 / 2408641$.

Whittaker, R.H. 1956. Vegetation of the Great Smoky Mountains. Ecol. Monogr. 26: 1-80. doi:10.2307/1943577.

Witter, J.A., and Ragenovich, I.R. 1986. Regeneration of Fraser fir at Mt. Mitchell, North Carolina, after depredations by the balsam woolly adelgid. For. Sci. 32: 585-594.

Yeh, F.C., Yang, R.-C., Boyle, T.B.J., Ye, Z.-H., and Mao, J.X. 2000. PopGene32, Microsoft Windows-Based freeware for population genetic analysis. Version 1.32. Molecular Biology and Biotechnology Centre, University of Alberta, Edmonton, Alta.

Young, A.G., and Boyle, T.J. 2000. Forest fragmentation. In Forest conservation genetics: principles and practice. Edited by A.G. Young, D. Boshier, and T.J. Boyle. CSIRO Publishing, Collingwood, Australia. pp. 123-134.

Young, A., Boyle, T., and Brown, T. 1996. The population genetic consequences of habitat fragmentation for plants. Trends Ecol. Evol. 11: 413-418. doi:10.1016/0169-5347(96)10045-8.

Ziegenhagen, B., Bialozyt, R., and Liepelt, S. 2004. Contrasting molecular markers reveal: gene flow via pollen is much more effective than gene flow via seeds. In Biological resources and migration. Edited by Dietrich Werner. Springer, Berlin, Germany. pp. 239-251. 